\title{
Innovations
}

\section{Doctors as mediators between two worlds: Biomedicine and socioeconomic realities in Arab societies (A reading through literary texts) Medical Humanities in the Middle East Conference}

\author{
November 17-18, 2018 \\ Doha, Qatar
}

\section{Authors}

\section{Faten Hussein ${ }^{*}$}

\section{Abstract}

In Western societies, several medical practitioners and theorists like Arthur Kleinman, Arthur Frank, Eric Cassell, and Rita Charon have been calling for a more human-oriented approach to the treatment of patients. Cassell for example argues for a return to healing: the original goal of medicine that is more comprehensive than just the curing of disease.' These calls respond to biomedicine with its predominant dualistic and reductionist mind-set. By biomedicine here I mean 'the evidence-based scientific model of medicine that originates in the
West and has come to dominate global healthcare from the latter half of the twentieth century'.2 The duality refers to 'the doctrine that separates the mental from the somatic'. ${ }^{3}$ The reductionist approach reduces the person to the disease, the physical malfunction that needs to be treated.

Biomedicine is the predominantly taught medicine in Arab universities. In Egypt, biomedicine is 'the national medicine'. ${ }^{4}$ This does not however entail that the dualistic approach is fully embraced in professional circles or public discourse on health in Arab countries. Medicine in Arab countries has a 'holistic orientation', where '[s]ickness is regarded as both psychosocial and physical maladaptation'. ${ }^{5}$ Doctors therefore often function as mediators between two worlds, reconciling two coexisting yet different medical paradigms while also operating
'Kings College London, London, United Kingdom

*Email: faten.hussein@kcl.ac.uk

Faten Hussein (10) https://orcid.org/0000-0001-6610-4994

\section{Cite this article as:}

Hussein F. Doctors as mediators between two worlds: Biomedicine and socioeconomic realities in Arab societies (A reading through literary texts) In: Weber AS, Verjee MA, editors. Proceedings of the lst International Conference on Medical Humanities in the Middle East [Internet]; 2018 Nov 17-18: Doha, Qatar: Innovations in Global Health Professions Education; 2019 March. p. 41-43. (Innovations in Global Health Professions Education; vol. 2019, spec. no.: 1). https://dx.doi.org/10.20421/ ighpe2019.01.14

This is an open access article distributed under the terms of the Creative Commons Attribution license CC BY 4.0, which permits unrestricted use, distribution and reproduction in any medium, provided the original work is properly cited. 
in often harsh socioeconomic environments that pose challenges to equal and proper access to healthcare. If they manage, they become what medical anthropologist Sherine Hamdy calls 'altabib al-muslim dhul-thiqqa', literally: a trustworthy Muslim doctor. The use of 'Muslim' here is more of a social than a religious concept. It signifies someone, who fears God and will act ethically towards his/her patients. This doctor is 'entrusted to adapt what is held to be a "universal science" [i.e. biomedicine] in the Egyptian context. [S/he] upholds "Egyptian" and religious values, and through his or her high ethical and scientific standards decides which medical practices are to be accepted'. ${ }^{6}$

In this paper, I will first address the two different systems of medicine doctors need to work with in the Middle East, within a specific socio-economic context. I will focus on modern Egypt, and will analyse the representation through $20^{\text {th }}$ and $21^{\text {st }}$ century Egyptian literature of an apparent clash of traditions, which proves more complex than it first appears. I will examine the manifestation of this apparent clash in religious and political discourse in modern Egypt, and their implication for patients as an example. I will then briefly address the question of bioethics in the Middle East, factors impacting bioethical discussions, and where to start a proper investigation of bioethical questions.

Though I refer to anthropological and political studies, my reading is based on literary texts. I mainly draw on Yahia Haqqi's Qandil Umm Hashim (The Lantern of Umm Hashim, 1944), Nawal al-Sa dawi's Mudhakkirat Tabiba (Memoirs of a Woman Doctor, 1958), and Shirin Hana'i's Tughra' (2013). These three texts allow us to trace the evolution of the issues addressed in this paper over a considerable span of time in Egyptian society. My presentation will show the persistence of the need for doctors to act as mediators between the world of their formal studies, and the cultural and socio-economic environment they operate in. Although over 70 years separate Haqqi and Hana' $i$, access to healthcare is still a burning issue. Disintegrating health systems in Arab countries is one of the major sources of grievances, which led to expressing discontent in the form of uprisings. Amidst issues of trust, competing loyalties to religion, science, or the state, and lack of proper bioethical training, trusted doctors are called upon to make the right decision for their patients.
The word for health in Arabic is 'Sihha', which also means justness, wholeness, and validity among other things. The root of the word is 'Sah', and among its meanings is 'to be true'. In this sense, health does not only involve help in restoring physical health, but includes being true to the doctor's vocation and to patients, to give validity to their suffering and attending to it. Healing, rather than curing, in short, is the goal of medicine, a concept my work is very much informed by.

\section{Conflicts of interest: None.}

Funding sources: None.

\section{References}

1. Cassell EJ. The healer's art: a new approach to the doctor-patient relationship. London, England: Penguin; 1978. 208 p.

2. Whitehead $A$, Woods A. Introduction. In: Whitehead A, Woods A, editors. The Edinburgh companion to the critical medical humanities. Edinburgh, Scotland: Edinburgh University Press; 2016. p. 1-32.

3. Engle GL. The need for a new medical model: a challenge for biomedicine. Science. $1977 \mathrm{Apr}$ 8;196(4268):129-36.

4. Hamdy S. Our bodies belong to God: organ transplants, Islam, and the struggle for human dignity in Egypt. Berkeley, CA: University of California Press; 2012. p. 43.

5. Morsy SA. Towards a political economy of health: A critical note on the medical anthropology of the Middle East. Soc Sci Med D. 1981 Apr;15(2):159-163. doi:10.1016/01607987(81)90039-9.

6. Hamdy S. Our bodies belong to God: organ transplants, Islam, and the struggle for human dignity in Egypt. Berkeley, CA: University of California Press; 2012. p. 36-7. 


\section{About the author}

Faten Hussein is a researcher in comparative literature and the health/medical humanities. She recently completed her PhD at King's College London, looking at the unravelling of repression in Arab societies through illness narratives. Faten published on her work for the American University in Cairo, and Routledge's Advances in the Medical Humanities series. 